\title{
Sustainability Reporting and Certification in Tourism
}

Ralf Buckley is Director International Centre for Ecotourism Research, Griffith University, Australia. E-mail r.buckley@griffith.edu.au

\section{Introduction}

Various forms of environmental certification and sustainability reporting are promoted by many industry sectors as a key component to self regulation, which is itself promoted as an alternative to government regulation. The tourism industry has a large number of different ecocertification schemes (Font and Buckley 2001; Black and Crabtree 2007), and these continue to grow and change. Academic evaluation of these initiatives is an important step in distinguishing those which do indeed contribute to improving environmental management and social sustainability, from those whose only effects are financial or political, or indeed those whose net environmental effects are negative. A recent Special Issue of this journal, edited by Jamal and Dredge (2011) presented seven recent case studies in this field. Here I conduct a meta-analysis of those studies to examine what they may reveal about overall progress in tourism ecocertification and sustainability reporting.

\section{Context: Human Societies, Sustainability and Self Regulation}

Current human society is unsustainable, in the fundamental sense that the planet cannot sustain it indefinitely: perhaps only for a few more decades. Many different alternative human societies might be sustainable, so we may disagree on the goal, but we agree on the direction: we must reduce aggregate human impacts on global natural environments. This requires either: a reduction in global human population; a reduction in mean per capita consumption, pollution and degradation of natural resources; or preferably, both at once. Technological advances may assist, but the fundamental changes are social. Sustainability therefore needs mechanisms for social change, and measures to determine how well they work.

The functioning of human societies is influenced strongly by large scale social structures, principally governments, corporations and religions. In each industry 
sector, sustainability is influenced by the interactions of government regulatory agencies, private companies, and individuals acting both as consumers and as voters or political advocates. Governments regulate industries so as to restrict the social, economic and environmental costs which private corporations impose on societies more broadly during the course of their commercial operations.

Industry representatives routinely argue against regulation on the grounds that it imposes costs on the corporations concerned. They may also argue that these costs reduce international competitiveness (Buckley 1993) or local financial viability, with consequences for local employment and prosperity. Individual companies are sometimes in favour of regulation where it gives them a competitive advantage, e.g., by creating barriers to entry for potential competitors. More commonly, however, industry associations lobby for reduced regulation, claiming that they will voluntarily operate in a socially and environmentally responsible manner.

There is now an extensive research literature analysing the policy context and practical dynamics of so called self regulation, and the degree to which governments of different ideological colour endorse or oppose this approach (Auld et al. 2008; Crane et al. 2008). It is worth noting that these negotiations extend only to social and environmental aspects of corporate behaviour. Neither governments nor industry, for example, suggest that paying taxes should be left to the responsible discretion of the companies concerned. At the scale of individual corporations, numerous analyses have now demonstrated correlations between financial performance and environmental performance in various sectors, including tourism (Rodriguez and Cruz 2007; Blanco et al. 2009).

Analyses of political process and corporate practice related to the negotiation of legislation, however, have demonstrated repeatedly that large corporations and entire industry sectors do not in fact regulate themselves effectively (Gunningham and Grabowsky 1998). Indeed, they devote considerable resources to political and public relations campaigns intended to avoid regulation (Beder 2002). There are strategic gains in doing so (Nunez 2007). This applies currently, for example, to very large scale and continuing campaigns to cast doubt upon the science of climate change in order to delay the imposition of carbon taxes or trading systems. 


\section{Sustainability and Social Responsibility Reporting}

As part of the continual interplay between governments and public interest groups seeking to regulate industry activities, and corporations and industry associations seeking to avoid such regulation, the concept has arisen of a social licence to operate, in parallel to formal compliance with applicable legislation (Crane et al. 2008). This context has generated pressures on private corporations to extend their reporting, for government and public as well as shareholders, so as to include information on social and environmental as well as financial performance. Such reporting, conducted under the banner of sustainability or corporate social responsibility (CSR), is still much weaker than financial reporting. This applies in all industry sectors, but in tourism especially (Buckley 2003; Ayuso 2007; Holcomb et al. 2007; Buckley and Pegas 2011).

Some corporate sustainability reporting initiatives are very vague and entirely voluntary, such as the Global Reporting Initiative (2011). Some have a defined format but voluntary adoption, such as environmental standards promulgated by the International Standards Organisation. Some have at least a quasi regulatory basis, such as the EU Eco Audit Scheme. Some are single company initiatives, such as annual sustainability, responsibility or environmental reports.

Social and environmental labels, awards and certification programmes fall within the broader category of voluntary corporate responsibility reporting. They are promoted as a mechanism for consumer choice, under which individuals can decide whether or not to make purchases from particular providers. This implies a parallel range of choice by corporations, which can decide individually on what environmental management practices to adopt and how to promote them. This is a very much weaker mechanism than environmental regulation by government, which commonly includes audit and penalty components. Regulation also provides environmental benefits for all those potentially affected, not only the company's customers.

In the tourism sector specifically, there are relatively few analyses of sustainability reporting more broadly (Buckley and Pegas 2011). There are, however, over 100 
ecocertification programmes (Black and Crabtree 2007; Font and Buckley 2001). Certification can substitute to some degree for sustainability reporting. Few ecocertification programs, however, incorporate rigorous accounting protocols, transparent disclosure, and third party audit. Different ecocertification programmes have very different structures, mechanisms, criteria and geographical scale.

There have therefore been extended negotiations over the past decade or longer to establish a higher-level global accreditation system for tourism ecocertification. These efforts were commenced by an environmental NGO, but were blocked by tourism interests (Buckley 2002a). The proposed global accreditation body was replaced with a consultative mechanism, the Global Sustainable Tourism Council, and a set of voluntary evaluation criteria known as the Global Sustainable Tourism Criteria, GSTC.

Multilateral government organisations have not been satisfied with this approach, and have established parallel mechanisms of their own, notably the UNEP Global Partnership for Sustainable Tourism. Various other organisations and individuals have also established websites and programs with very similar names, capitalising on the publicity associated with these initiatives, for their own commercial purposes. The net effect is of very heavily muddied waters, and confusion in the eyes of potential users.

Individual tourism eco-certification programmes in different parts of the world have continued to operate independently of these larger-scale political manoeuverings, fading or proliferating as finances or politics dictate, and largely ignored by individual retail consumers and their travel agents. Most of them focus more on management processes than environmental outcomes. Few set quantitative technical performance standards. Rigorous audits are rare, and many are largely or completely lacking in public transparency. This applies both to the broader ecocertification programmes which have been operating for a decade or more, and to climate- and carbon-related schemes which have arisen more recently.

Perhaps because of the lack of transparency and consumer interest, tourism industry ecolabel, ecocertification and eco-award programmes remain relatively little studied 
in the literature of tourism research. The recent special issue (Jamal and Dredge 2011) aims to address this lack of attention, by providing seven new case studies, drawn from a wide range of different geographic areas and sociocultural milieux. Here, therefore, I examine these studies within the context outlined above in order to assess progress in tourism sustainability reporting.

\section{Summaries of the Case Studies}

Akama et al. (2011) discuss international safari tourism in Kenya from a "post colonial" perspective, a field in which Akama has longstanding research expertise. The article refers only to the Maasai, with no mention of Kenya's other peoples. It says that the Maasai should keep their cattle where they want, including national parks used for wildlife conservation and tourism. It argues that livestock and wildlife coexisted successfully in pre-colonial times, but fails to note that densities of people and cattle were increased greatly by colonial-era tsetse eradication and improved infant health. It argues that the Maasai have rights to self-determination. Maybe, but not over tourists. If the Maasai want money from tourists watching wildlife in parks, they'll have to move their cattle out. This is a market issue, not a political one. It argues that tourism certification programs should use social rather than environmental criteria. The criteria it proposes include differential distribution of benefits to the poorest locals, and access to protected areas for traditional uses. These issues, however, are outside the control of tourism operators. They are also routinely disagreed within local communities. In addition, they ignore modernisation in local communities, which often modify traditional practices and technologies in ways which increase environmental impacts.

Scherrer and Doohan (2011) provide an intriguing though turgid perspective on tourism in Australia's Kimberley region. They focus on small-scale coastal cruise tourism, described recently in another publication by Scherrer et al. (2011). From the viewpoint of the indigenous Aboriginal peoples: tourists are strangers; visiting without formal permission constitutes trespass; and within Aboriginal worldviews, this can cause misfortune. Thus, footprints on a tidal beach have negligible physical impacts, but create cultural impact. Scherrer and Doohan (2011) propose cash payments to buy cultural acceptance: Aboriginal residents want tourism to provide 
money, not ecocertification. But such payments have already been demanded in parts of the Kimberley for over a decade, and have not generated cultural respect in either direction. So this is unconvincing.

Herremans et al. (2011) investigated $~ 300$ "multinational corporate powerhouses" in tourism, from company websites. Only $4 \%$ provide externally assured sustainability reports, as compared with $40 \%$ of Global 250 companies across all sectors. China is slightly ahead, but India is weak. Airline companies are under greatest social pressure, and CSR reporting is somewhat higher. Overall, Herremans et al. (2011) found that "the tourism industries are not meeting the commitments of the Davos Declaration and WTTC". Given that these commitments were themselves tourism industry initiatives, such failure is particularly acute.

Grosbois and Fennell (2011) compared how 150 large hotel groups claim to assess and report carbon footprints, according to corporate websites. Carbon footprint reporting is uncommon, ambiguous, and unverified. Companies convert their claims to "trees planted" or "cars taken off the road", using undefined conversion factors. According to Grosbois and Fennell (2011), for example, ITC Welcomegroup “declared itself to be a 'carbon positive' corporation which created 'certifiable carbon credits' but without reporting its carbon footprint (or carbon credit) in any form".

Bricker and Schultz (2011) tested 13 of 23 State scale tourism certification programmes in the USA against the 37 Global Sustainable Tourism Criteria. Given the role and history of the GSTC as outlined above, such comparisons are valuable. Their analysis gains power by testing the individual certified participants, rather than the certification schemes, against the GSTC. It loses power, however, since it is based only on self-reported responses by a self-selected $11 \%$ sample. Self selection biases results to companies who see competitive advantage in responding. Self reporting means that responses are both unverified, and meaninglessly imprecise. For example, energy conservation, claimed by $>90 \%$, might mean turning off one light. Measuring purchases of disposables (80\%), might only mean keeping tax receipts. Contributing to biodiversity conservation (70\%), might only mean paying taxes which inter alia fund the national parks service. 
Baddeley and Font (2011) used a supply chain approach to examine how UK based tour packager Thomas Cook has tried to apply the newly formed EU wide industry scheme "Travelife". The key issue is that when voluntary environmental initiatives conflict with compulsory health and safety regulations, the latter take precedence (Font and Buckley 2001). Baddeley and Font (2011) showed that amongst Thomas Cook's suppliers, concerns over possible health and safety lawsuits, either real or claimed, lead them to avoid opportunities to improve environmental performance.

Mbaiwa et al. (2011) reported on the establishment of a national tourism ecocertification program in Botswana. This seems to be a separate piece of research than that published by Mbaiwa (2011) and Mbaiwa and Stronza (2011) on tourism, resident attitudes and sustainable livelihoods in the same geographical area. The ecocertification scheme has three tiers and 280 criteria, and uses a checklist based approach similar to the well established Australian program. The majority of businesses interested in this scheme are wildlife lodges in the Okavango area, and Mbaiwa et al. (2011) summarised their self reported performance against selected indicators. Largest of these operators is Wilderness Safaris, with 19 camps and lodges. Independent audits of this company (Buckley 2010) indicate generally high environmental performance, at least as good as in Australia or elsewhere. There is thus no fundamental technical limitation to world standard ecocertification in Botswana.

\section{Comparative Analysis}

Given the large number of tourism ecocertification programmes, environmental award schemes and individual corporate sustainability reporting initiatives worldwide, it is clear that these seven case studies cannot provide comprehensive coverage of this field. They do, however, provide a reasonably representative set, with two on local scale communities, two on large scale mainstream tourism, and three on new initiatives. Akama et al. (2011) and Scherrer and Doohan (2011) consider the local concerns of Indigenous peoples in Africa and tropical Australia respectively. In the Kimberley, it appears that Aboriginal communities have no particular interest in certification programmes. At least as presented by these authors, the Aboriginal 
peoples concerned see themselves as suffering a cultural impact. Even though the type of impact concerned is essentially religious rather than material, their proposed remedy is monetary compensation rather than religious respect: essentially, cash for sacrilege. A cynic might see this as an indirect technique, legitimate or otherwise depending on one's perspective, to extract a resource rent for access to an area over which one does not have recognised modern legal title. In any event, it seems that the proposal by outsiders that an ecocertification programme would help to reduce impacts was not well received by local residents.

In the African case, the adoption of a post colonial political stance appears to ignore the commercial realities of the tourism industry. Different individuals may well hold different views as to whether or not local Maasai should or should not be allowed to graze their cattle in Ngorongoro Crater National Park, and if so when and where. That is a legal, political and sociocultural issue. But if they do so, whether legally or illegally, sanctioned or not, they will drive away tourists. Tourists come to see wildlife, not cows. Cows damage the park, and hence the tourism industry. Locals may not care about either. They can use post colonial politics to sanction cattle grazing inside the park, and they can use grazing damage as a weapon to extract more money from tour operators. What they cannot do is to have both large-scale pastoralism and a successful wildlife tourism industry. Cows or cash, simple choice. Once again, therefore, certification based approaches seem to be of little relevance in these circumstances. Even if a new set of socially oriented certification criteria were established, so that tourists would know whether or not a particular operator had taken steps to reduce cultural impacts, that does not seem to be a criterion which either the tourists nor the local residents care about.

Two of the chapters refer to large scale reviews of mainstream tourism enterprises, principally in the hospitality sector. The evidence presented in both these chapters indicates that in general, environmental management in these sectors is weak, and certification programmes are not effective in improving it. These chapters present broad results from relatively large samples, reflecting industry averages rather than individual leaders. There may well be individual companies with exemplary practices, but ecocertification does not provide any guarantee of this. It does not even act as a reliable indicator, since the majority of ecocertified enterprises have very 
mediocre practices. One of the claimed aims and potential benefits of ecocertification programmes in any industry sector is to bring the laggards closer to the leaders, and hence improve aggregate performance across the entire sector (Buckley 2002b). The programmes described by Herremans et al. (2011) and Grosbois and Fennell (2011), however, do not seem to have been very effective in this regard.

Three of the chapters describe recent initiatives in tourism ecocertification. The new ecocertification programme designed in Botswana (Mbaiwa et al. 2011) uses a simple and well tried structure, and customised criteria from within its own local industry. Its members include some of the world's leading conservation tourism operators. These, at least, are companies whose founders and clients really do have personal interests in conservation, and which really do have a financial interest in differentiating themselves reliably from less conscientious competitors. Whilst it is as yet new, therefore, the Botswana scheme may well have a good chance of success. This, however, is because the companies spearheading the new scheme already have very good environmental credentials, which they already market very effectively to their own clienteles. Ecocertification merely provides recognition, not incentives.

The EU Travelife programme is also new, and its environmental outcomes remain to be seen. The results presented by Baddeley and Font (2011) however, indicate that it is hampered by perceived conflicts with human health obligations. This issue has been recognised for two decades (Canadian Pacific Hotels 1992; International Hotels Environment Initiative 1996; Font and Buckley 2001). It does seem rather surprising and unfortunate, therefore, that it was not anticipated in the design of the Travelife programme.

The GSTC are new but operational, and Bricker and Schultz (2011) provide what appears to be the first published test. Such tests are indeed critical in evaluating and improving the performance of ecocertification programmes. This particular study, however, is restricted to second tier (State-scale) programmes within one country, and there is no a priori reason to presume that these are particularly high performing programmes. The study tests the programmes against the GSTC, but it does not test the effectiveness of the GSTC in improving environmental management in tourism. The individual criteria are so limited in technical detail that the reader cannot judge 
their significance for practical environmental management. This suggests that the GSTC are unlikely to yield any improvement in environmental management in tourism. Indeed, they are much more likely to have the reverse effect, if they are used by the industry to argue that it is capable of adequate voluntary self regulation and therefore need not be subjected to government regulation.

\section{Conclusions}

In summary, Jamal and Dredge (2011) present a cross section of case studies which cover Indigenous community issues, mainstream hospitality, and new initiatives; and there seems little indication that ecocertification approaches have yielded any improvement in environmental outcomes in any of these cases. This does not mean that certification approaches should be dismissed, because they are used widely in other industry sectors and in some cases are highly effective. The role of national medical associations in certifying the competence of individual doctors is a case in point. These systems, however, took generations to become effective, and they were driven by strong consumer pressure: people were being killed by quacks.

For eco-certification in tourism, the dynamics are very different. There are four main stakeholder groups, and only a few individual players in each have a strong stake in effective ecocertification systems. The majority of members in each group have more to gain from ineffective systems whose real aims are not to contribute to improved environmental management, but to subvert it. Most private tourism enterprises and industry associations want cheap and easy certification as a minor component in marketing strategies. Only those few with the best environmental bottom lines have interests in effective ecocertification programmes which differentiate them clearly from competitors. Most government tourism agencies are also concerned mainly with marketing. They also want certification programmes which are weak technically but powerful politically, so as to attract more international tourists, or gain commercial access to protected areas. Only a few individuals with personal interests in improved environmental management, or professional investment in ecocertification programmes, have an incentive for effective differentiation. Government parks agencies may make more functional use of tourism ecocertification, but generally establish their own, which they can then rely on (Ingram 2007). 
Most individual tourists, the retail consumers of the tourism industry's products, are concerned more about environmental quality at tourist destinations than environmental performance of tourism enterprises; and they think that it is the responsibility of government to regulate and monitor both. Only a few individual tourists deliberately select tour operators with good environmental credentials, and their focus is more on natural history interpretation and conservation contributions than on day to day environmental management. Most travel agents promote particular products on the basis of company commissions and customers' socioeconomic circumstances, with no reference to certification of any form.

Environmental NGOs do indeed have interests in ecocertification, and one such NGO, the Rainforest Alliance, was a leader in early though unsuccessful moves to establish a global accreditation programme for national tourism ecocertification programmes. It was these efforts that led to the GSTC (Bricker and Schultz 2011), a greatly weakened alternative to the original initiative. The same NGO did successfully set up the Forestry Stewardship Council, and with the help of celebrity endorsement, persuaded large retail hardware supply chains to stock only FSC certified timber. A similar approach in tourism would require firstly the establishment of a global Tourism Stewardship Council, and secondly an agreement by major travel agents and tour packagers to sell only TSC certified products. The GSTC may be a first small step towards a TSC, or it may be a sidestep designed to block the TSC. As Bricker and Schultz (2011) show, it is not currently very effective in improving environmental management.

At the same time, large packagers and agents such as Touristik Union International and World Hotel-Link have tried supply chain and customer to customer approaches, also with limited success; and as Baddeley and Font (2011) show, the latest entrant in this race, the Travelife program in Europe, does not seem to have learned well from past lessons. In addition, the European Union is currently developing its own sustainability indicators for tourism destinations, with reference to two previous EU studies but not to Travelife. Similarly, the United Nations Environment Program has established its own Global Partnership for Sustainable Tourism, without any formal link to the industry-based GSTC. Confusion reigns supreme. 
So, it seems that the simplest and most direct approach, such as that now being introduced in Botswana, may well prove the most effective. Time will tell, and it is up to the tourism research community to test the outcomes and effectiveness of these schemes in a rigorous manner, from an independent standpoint.

Ralf Buckley

International Centre for Ecotourism Research

Griffith University, Gold Coast, Australia 4222

www.griffith.edu.au/centre/icer 


\section{References}

AKAMA, J.S., MAINGI, S. and CAMARGO, B.A. (2011). Wildlife Conservation, Safari Tourism And The Role Of Certification In Kenya. Tourism Recreation Research, in press.

AULD, G., BERNSTEIN, S. and CASHORE, B. (2008) The New Corporate Social Responsibility. Annual Review of Environment and Resources, 33: 413-435.

AYUSO, S. (2007) Comparing Voluntary Policy Instruments For Sustainable Tourism: The Experience Of The Spanish Hotel Sector. Journal of Sustainable Tourism, 15: 144-159.

BADDELEY, J. and FONT, X. (2011). Barriers To Tour Operator Sustainable Supply Chain Management. Tourism Recreation Research, in press.

BEDER, S. (2002). Global Spin: The Corporate Assault on Environmentalism. Devon: Green Books. 336 pp.

BLACK, R. and CRABTREE, A. (2007). Quality Assurance and Certification in Ecotourism. Wallingford. CAB International. 516 pp.

BLANCO, E., REY-MAQUIEIRA, J. and LOZANO, J. (2009) Economic Incentives For Tourism Firms To Undertake Voluntary Environmental Management. Tourism Management, 30: 112-122.

BRICKER, K. and SCHULTZ, J. (2011). Sustainable Tourism In The USA: A Comparative Look At The Global Sustainable Tourism Criteria. Tourism Recreation Research, in press.

BUCKLEY, R.C. (1993). International Trade, Investment and Environment: An Environmental Management Perspective. Journal of World Trade 27(4): 102-148. 
BUCKLEY, R.C. (2002a). Tourism Ecocertification in the International Year of Ecotourism. Journal of Ecotourism 1: 197-203.

BUCKLEY, R.C. (2002b). Tourism Ecolabels. Annals of Tourism Research 29: 183 208.

BUCKLEY, R.C. (2003). Environmental Inputs and Outputs in Ecotourism Geotourism with a Positive Triple Bottom Line? Journal of Ecotourism 2: 76-82.

BUCKLEY, R.C. (2010). Conservation Tourism. Wallingford. CAB International. 214 pp.

BUCKLEY, R.C. and PEGAS, F. (2011). Tourism and Corporate Social Responsibility. In Holden, A. and Fennell, D. (eds) Handbook of Tourism and Environment. Routledge (in press).

CANADIAN PACIFIC HOTELS (1992). Green Partnerships. CPH. Montreal.

CRANE, A., MCWILliAMS, A., MATTEN, D., MOON, J. and SIEGEL, D.S. (eds) The Oxford Handbook of Corporate Social Responsibility. Oxford: Oxford University Press.

FONT, X. and BUCKLEY, R.C. (eds) (2001). Tourism Ecolabelling. Wallingford. CAB International. $359 \mathrm{pp}$.

GLOBAL REPORTING INITIATIVE (2011). http://www.globalreporting.org/Home - Accessed on 18 July 2011.

GROSBOIS, D. de and FENNELL, D. (2011). Carbon Footprint Of The Global Hotel Companies: Comparison Of Methodologies And Results. Tourism Recreation Research, in press.

GUNNINGHAM, N. and GRABOWSKY, P. (1998). Smart Regulation. Oxford. Clarendon. 
HERREMANS, I.M., PYASI, N. and LU, J. (2011). The Journey Towards Sustainability: How Accountable Are The Tourism Industries? Tourism Recreation Research, in press.

HOLCOMB, J.L., UPCHURCH, R.S. and OKUMUS, F. (2007) Corporate Social Responsibility: What Are Top Hotel Companies Reporting? International Journal of Contemporary Hospitality Management, 19: 461-475.

INGRAM, C. (2007). Certification in Protected Areas. A Western Australian Case Study. In Black, R. and Crabtree, A. (eds) Quality Assurance and Certification in Ecotourism. Wallingford. CAB International. 266-298.

INTERNATIONAL HOTELS ENVIRONMENT INITIATIVE (1996). Environmental Management for Hotels - The Industry Guide to Best Practice. Oxford. Butterworth-Heinemann. 236 pp.

JAMAL, T. and DREDGE, D. (eds) (2011). Special Issue on Sustainability Reporting and Certification. Tourism Recreation Research (in press).

MBAIWA, J.E. (2011). Changes on Traditional Livelihood Activities and Lifestyles Caused by Tourism Development in the Okavango Delta, Botswana. Tourism Management 32: 1050-1060.

MBAIWA, J.E. and STRONZA, A.L. (2011). Changes in Resident Attitudes Towards Tourism Development and Conservation in the Okavango Delta, Botswana. Journal of Environmental Management 92: 1950-1959.

MBAIWA, J. et al. (2011). [final title?] Tourism Recreation Research, in press.

NUNEZ, J. (2007) Can Self Regulation Work? A Story Of Corruption, Impunity And Cover-Up. Journal of Regulatory Economics, 31: 209-233. 
RODRIGUEZ, F.J.G. and CRUZ, Y.M.A. (2007) Relation Between SocialEnvironmental Responsibility And Performance In Hotel Firms. International Journal of Hospitality Management, 26: 824-839.

SCHERRER, P. and DOOHAN, (2011). [final title?] Tourism Recreation Research, in press.

SCHERRER, P., SMITH, A.J., and DOWLING, R.K. (2011). Visitor Management Practices and Operational Sustainability: Expedition Cruising in the Kimberley, Australia. Tourism Management 32: 1218-1222. 